\title{
Gauging the Deliverable? Educational Research in Northern Ireland
}

\author{
JOHN GARDNER \& TONY GALLAGHER \\ Queen's University Belfast, United Kingdom
}

\begin{abstract}
This article considers the landscape for educational research in the smallest country of the United Kingdom, Northern Ireland. As elsewhere, educational research exists in political and economic circumstances that have considerable influence on its direction, nature and purpose and this article seeks to contextualise these influences. Northern Ireland differs considerably from the other three jurisdictions by virtue of it being very small (a population of circa 1.5 million), a fact that creates systemic difficulties such as capacity weaknesses in both numbers of researchers and the range of research skills available. Perhaps most importantly, however, Northern Ireland is uniquely distinguished from England, Scotland and Wales by having a proportionately large selective education system (grammar and non-selective secondary schools) and a politically and religiously divided population. This article argues that in combination with such national pressures as the Research Assessment Exercise, these contextual features result in a largely instrumental role for educational research $-\mathrm{a}$ tool to gauge what policy changes are deliverable. A strategic direction based on a dialogue between the government and the researcher community is therefore needed to prevent the continuation of a perceived ad hoc and fragmented system of educational research. The challenges of building a thriving research community in such circumstances also include the need to promote innovative ideas and related research, and to encourage greater inter-institutional collaboration. This in turn, it is argued, will help to create a community of practice capable of both sustaining itself in the future and making available a broader range of research competence.
\end{abstract}

The question in the title derives from a 2003 statement by the head of the Northern Ireland Civil Service (Hamilton, 2003). In the Foreword to A Practical Guide to Policy Making in Northern Ireland he counsels policy developers to recognise that those involved in the front line of service delivery, whether in schools, hospitals or social security offices ... have a vital role in helping to gauge what is deliverable' and should be engaged early in the process of policy development. The guide itself, drawn up in 'response to the increasing demand for policy development and advice by the Northern Ireland Civil Service following devolution', goes on to advise that gathering the necessary evidence

through interviews, surveys or focus groups can provide a very valuable input to the policy making process and can often be done much more quickly than more conventional research. It may well also help to avoid expensive mistakes later. (p. 23)

Setting aside the begged question about what 'more conventional research' might imply, research would appear not to be seen as something that necessarily increases our understanding. Nor is it seen, as in some medical or scientific contexts, as the source of innovation and breakthrough. Not unreasonably perhaps, research for policy makers in Northern Ireland is more likely to be viewed as a pragmatic step in ensuring that new policy and its implemented practice have some prospect of successful delivery. Educational research in Northern Ireland, therefore, has arguably been promoted primarily to meet a departmental need for reassurance rather than any loftier role in developing new knowledge, insights and understandings. This article explores the provenance and 
context of this instrumentalist approach through a lens that sets out the history and structures of the education system in Northern Ireland.

\section{Political Context}

Northern Ireland has always had an idiosyncratic existence within the United Kingdom (UK). It was formed in 1921, when the island of Ireland was partitioned, and operated until 1972 as a semiautonomous region of the UK with its own parliament and government, including a Ministry of Education. Following the Second World War the Northern Ireland Government opted broadly to follow the pattern of social policy adopted in Great Britain with the introduction of the welfare state and the extension of compulsory education. Legislation in Northern Ireland typically followed British practice, although often with a time lag of a few years - explained by some as enabling teething problems to be ironed out in Great Britain before implementation in Northern Ireland. Over the period since partition, a variety of local political parties has represented the various perspectives. The mainstream Labour and Conservative parties of Great Britain now operate in Northern Ireland after years of refusing local requests to do so, with the Labour Party relenting only in the last three years, but they have few members and little electoral support.

In 1972 the Northern Ireland parliament was prorogued as a consequence of political violence. Apart from a brief hiatus in 1974 no local parliament functioned until 2000 though it must be emphasised that a local administration remained in place throughout. Policy makers within this administration, and specifically education policy makers in the context of this article, continued to commission research according to their own priorities. Throughout this period Northern Ireland was under the 'direct rule' of the Westminster Parliament with ministers appointed by the London government and a secretary of state who sat in the Downing Street cabinet. Since 1985 the government of the Republic of Ireland has had an input to policy development in Northern Ireland as a consequence of the Anglo-Irish Agreement.[1] Ceasefires were declared by the main paramilitary organisations in 1994, ultimately leading to a peace agreement being signed by most of the political parties in Northern Ireland in 1998. Part of the agreement involved the establishment of a Northern Ireland Assembly, though this did not actually begin to function until 2000. Due to internal political problems it was suspended in 2002 and, at the time of writing, it has not yet been restored to operation.

The Assembly of 2000-02 incorporated a number of unusual features that reflected its genesis in a peace agreement designed to end more than a quarter of a century of political violence. Ministerial posts in the Assembly Executive were allocated under a special arrangement, the d'Hondt system (for a simple illustration, see Elliot, 2006), to ensure a coalition arrangement between the main unionist (Ulster Unionist [UUP] and Democratic Unionist [DUP]) and nationalist (Sinn Fein $[\mathrm{SF}]$ and Social, Democratic and Labour [SDLP]) political parties. The number of existing direct-rule departments was expanded to ensure that all four parties received some departmental portfolios. Between 2000 and 2002 these 'power sharing' arrangements meant that aspects of education were split across three ministerial departments in the Assembly: the Department of Education (DE) with responsibility for schools; the Department of Employment and Learning (DEL) with responsibility for tertiary education, including teacher training, and employment training; and the Department of Culture, Arts and Leisure (DCAL) with responsibility for, inter alia, the arts and museums. Sinn Fein held the departmental portfolio for Education, the Social Democratic and Labour Party held the portfolio for Employment and Learning and the Ulster Unionist Party held the portfolio for Culture, Arts and Leisure.

With its remit for schools, education policy is determined by the Department of Education, though this has to operate within the wider policy context provided by the Northern Ireland Office. The Education and Training Inspectorate (ETI) [2] operates as a professional branch within the departments of Education, and Employment and Learning, and has responsibility for a wide range of inspection services in the school, youth and teacher education sectors. It has a broadly similar role to Her Majesty's Inspectorates (HMIs) in Scotland and Wales and the Office for Standards in Education (Ofsted) in England and represents a direct link to the oldest schools' inspectorate in the British Isles, the pre-partition National School Inspectors of Ireland. (Despite being a longer 
established body than its HMI counterparts, ETI has never had the Privy Council charter and therefore its inspectors not called Her Majesty's Inspectors.)

Key decisions of the Assembly have to pass rules of 'sufficient consensus' such that they receive the support not only of a majority of Assembly members voting, but also of no fewer than $40 \%$ each of the members of the unionist and nationalist blocs. This requires all Assembly members, on taking their seats, to designate themselves as unionists or nationalists. For each ministerial portfolio an Assembly committee scrutinises the work of the department concerned. The chair and vice-chair of each committee are allocated to different political parties as part of a balancing mechanism.

\section{Educational Context}

Schools

For historical reasons schools in Northern Ireland are divided on a denominational basis, although almost all schools are publicly funded. Brady (2006) has collated religious affiliation data from Department of Education sources for school types in both sectors and the data for 2003-04 are summarised in Table I.

\begin{tabular}{lccc}
\hline School Type & \multicolumn{3}{c}{ Religion of students } \\
\cline { 2 - 4 } & Catholic & Protestant & Other $^{\star \star}$ \\
\hline Primary schools & 98.1 & 0.9 & 0.9 \\
Catholic maintained $(n=414)$ & 4.1 & 80.6 & 15.3 \\
State controlled $(n=427)$ & 30.9 & 49.9 & 19.3 \\
State controlled integrated $(n=13)$ & 43.6 & 36.1 & 20.2 \\
Grant maintained integrated $(n=19)$ & & & \\
& & & \\
Secondary (non-selective) schools & 99.1 & 0.4 & 0.5 \\
Catholic maintained $(n=76)$ & 1.7 & 86.9 & 11.4 \\
State controlled $(n=68)$ & 15.7 & 68.8 & 15.6 \\
Controlled integrated $(n=4)$ & 45.7 & 42.3 & 12.1 \\
Grant maintained integrated $(n=14)$ & & & \\
& & & \\
Grammar $($ selective $)$ schools & & & \\
Catholic management $(n=31)$ & 99.0 & 0.6 & 0.4 \\
State controlled $(n=17)$ & 6.0 & 81.0 & 13.0 \\
Voluntary $(n=22)$ & 8.8 & 71.1 & 20.1 \\
\hline
\end{tabular}

*The figures given are subject to rounding errors;

${ }^{\star}$ Includes other Christian, non-Christian and not recorded/no religion.

Table I. Religious affiliations of students in the various school types.

Thus there are parallel systems of Catholic and non-denominational primary, secondary and grammar schools, which have existed since the inception of the state. The long-standing gulf between the sectors is emphasised by the fact that it was not until 1964 that a prime minister of Northern Ireland visited a Catholic school. The relatively new sector comprising integrated schools has operated since 1981 and in the last 10 years has managed to double its number of secondarylevel schools (from 9 to 18 ), though this still covers only around $5 \%$ of the total school population.

\section{Administrative Organisations}

Although under review and with major changes projected for the autumn of 2006, Education is currently administered by five education and library boards (ELBs), which are broadly equivalent to local authorities in Britain. However, they are primarily administrative bodies with a limited policy role. Due to the size of the Catholic school sector, and the autonomy enjoyed by many grammar and integrated schools, the ELBs directly control less than half of all schools. A majority of the members of each board are appointed by the Secretary of State with a minority of representatives nominated by local councils. 
Each ELB operates a Curriculum Advisory Support Service (CASS) and collectively the five boards have established the Regional Training Unit (http: / www.rtuni.org) to provide training and support on strategic issues, most notably school leadership. The Council for the Curriculum, Examinations and Assessment (http://www.ccea.org.uk) has responsibility for the statutory curriculum and assessment arrangements for schools while the General Teaching Council (http://www.gtcni.org.uk) is the regulatory body for the teaching profession. There are a number of representative bodies for specific school sectors. Those that receive public funding include the Council for Catholic Maintained Schools (http://www.onlineccms.com), the Northern Ireland Council for Integrated Education (http://www.nicie.org) and Comhairle na Gaelscoilaíochta (http://www.comhairle.org, the Council for Irish Medium Education). Those not in receipt of public funding include the Transferors' Representative Council (TRC, representing the Protestant Churches) and the Governing Bodies Association (http://www.governingbodiesassociation.com, representing the governors of the voluntary grammar schools).

\section{The Context of Educational Research}

In the 1960s and 1970s the Northern Ireland Government funded an Advisory Council on Education, which investigated various issues and funded research to inform its deliberations. Thus, for example, a report of the Council in 1973 (Burges Report, 1973) recommended the end of academic selection at age 11. In the 1970s the Council was reconstituted as the Northern Ireland Council for Education Research (NICER), which provided a forum for educational interests. NICER's research work was funded direct from the Department of Education and was housed in the School of Psychology in Queen's University. In 1994 the Government decided formally to cease funding NICER and the staff and commitments were transferred to the School of Education at Queen's University. From this point onwards, department funds for educational research were used to fund targeted projects, which would inform departmental policy, or were made available for academics through a competitive application process.

In common with other regions, funding for educational research in Northern Ireland comes from a variety of sources. Each of the government departments has a small research budget but, of the bodies mentioned above, only the Council for Curriculum, Examinations and Assessment has a designated research budget. The education and library boards occasionally fund work that is linked to educational research, though this normally has a development focus and is often run through the Regional Training Unit. There are also a number of non-departmental public bodies (NDPBs, formerly known as quangos) which have small research budgets and occasional participation in education-related work. These include the Equality Commission (http://www.equalityni.org), the Human Rights Commission (http://www.nihrc.org) and the Commissioner for Children and Young persons (http://www.niccy.org). The precursors to the Equality Commission, the Fair Employment Commission (religion), the Equal Opportunities Commission (gender) and the Commission for Racial Equality (race), all had small research budgets and funded some educational research.

A number of charities and trusts have provided significant funds for social research of all kinds, including education, over many years. These include the Joseph Rowntree Charitable Trust (http://www.jrct.org.uk), the Nuffield Foundation (http://www.nuffieldfoundation.org) and the CfBT Education Trust (http://www.cfbt.com). However, probably the most significant organisation within the non-governmental sector has been the US-based Atlantic Philanthropies (http:/ / www.atlanticphilanthropies.org) which has funded a wide variety of activities over recent years. Industrial and commercial sponsors of research are very thin on the ground but one group, Astra-Zeneca, has funded several initiatives in science education research.

Academics also seek funds from the research councils, especially the Economic and Social Research Council (http://www.esrc.ac.uk). The European Commission has funded research and development in Northern Ireland over many years, and established a special Peace and Reconciliation Fund (http://www.eugrants.org/peace_summary.pdf) to support social and economic programmes aimed at promoting social inclusion in the wake of the paramilitary ceasefires. Although a proportion of these funds was targeted on education work, much of it has 
been focused on development rather than research. As a consequence, the bulk of the funds has gone to non-governmental organisations and local voluntary and/or community organisations.

The total quantum of government funds available for research is limited: for example, the

Department of Education has a budget allocation of approximately $£ 300,000$ on average per annum, with variations in the total caused by run-on costs from existing projects. Additional funds are provided for special initiatives: in recent years this has included the cost of Northern Ireland's participation in the Programme for International Student Assessment (PISA), and a contribution to the Economic and Social Research Council's Teaching and Learning Research Programme (http://www.tlrp.org) to support Northern Ireland extensions to British projects. Occasionally there are special allocations for priority policy issues, such as research into the effects of the selective system of secondary education and the National Foundation for Educational Research (http://www.nfer.ac.uk) cohort studies in relation to students' views of the statutory curriculum (for example, Harland et al, 2003; Moor et al, 2004).

Much larger sums of money than the nominal $£ 250,000$ appear to be available to the Department of Education for spending on consultancy services. For example, before its demise in 2002, the Northern Ireland Assembly Public Accounts Committee queried the Department of Education's spending of almost $£ 4.3$ million on education-related consultancy during the period between 1998 and 2002 (PAC, 2002). Of this $89 \%$ ( $£ 3.8$ million) went to one company, PricewaterhouseCoopers. These funds were allocated through a restricted competition among a list of approved tenderers, known as the Consultancy Framework. This list of consultancies is maintained by the Central Procurement Directorate (http://www.cpdni.gov.uk) for all government departments and their agencies. In the most recent framework, only two academic groups were listed under the category 'Projects': the Institute of Child Care Research and the Institute of Governance, Public Policy and Research, both at Queen's University. Applicants for approved status must respond to a public advertisement and, subject to a positive evaluation, are then listed for three years. The most recent advertisement appeared in the Official Journal of the European Union under the title: 'UK-Belfast: general management consultancy services' (Official Journal of the European Union, 2005).

During the Public Accounts Committee meeting, a senior Department of Education official explained that the bulk of the expenditure on consultancy services was for such things as advice on information technology developments, public-private procurements and other specialist areas that lie outside the scope of the Department's in-house skills. Inspection of the list of awards made by the Central Procurement Directorate substantially bears this out. For example, in the period April to August 2005, 171 contracts were awarded on behalf of all of the departments and these ranged from the supply of 'Spare Parts for Lorries' to 'Economic Appraisals'. Only three contracts were awarded on behalf of the Department of Education and these related to such non-research areas as insurance services for the General Teaching Council, internal audit services for the Council for the Curriculum, Examinations and Assessment and portable electrical testing services for the Council for Catholic Maintained Schools.

In the same period at least two, arguably research-related, contracts would appear to have been awarded to consultants on behalf of the Department of Employment and Learning for 'Essential Skills Qualitative Research' and 'Evaluation of Jobskills' but there is insufficient detail to confirm this. However, there is less ambiguity about an earlier award for an Independent Evaluation of the Inspection Process', which, prime facie, would appear to fall within the normal definition of academic research. Awarded in 2001 to PricewaterhouseCoopers, this contract and the select tender process first came to light when one of the present authors, who at the time had recently published on the inspection process in Northern Ireland (Gray \& Gardner, 1999), wrote to the Chief Inspector to ask why the opportunity to bid for the research had not been made available to local educational researchers. As with most of the work carried out under this type of process, the report was not published.

\section{Who Carries out Educational Research?}

As a consequence of a strong voluntary and community sector, and the availability of funds for locally-based development projects, there is a myriad of educational projects being implemented 
across Northern Ireland. Many of these projects involve some element of research or evaluation and a number of voluntary sector groups have emerged to provide expertise and support for this work. However, relatively little of this work is published or subject to peer review. In practice, therefore, the number of people involved in formal academic research in education is quite small. The UK Research Assessment Exercise (RAE) throws this into sharp relief compared with other regions. There are two universities in Northern Ireland, Queen's University Belfast and the University of Ulster, with the Open University maintaining a largely administrative out-centre in Belfast. There are also two teacher education colleges, Stranmillis University College and St Mary's University College, both of which are associate colleges of Queen's. In the 2001 RAE only Queen's and Ulster submitted returns to the Education Unit of Assessment. The Queen's submission included 18 staff and received a grade 4, while the Ulster submission included 20.5 staff and received a grade $3 \mathrm{a}$. On the basis of the exercise there were therefore only 39 research-active staff in Northern Ireland higher education, in comparison with 77 (6 submissions) in Wales, 163 (6 submissions) in Scotland and 1767 (69 submissions) in England (RAE, 2001).

Clearly, the total number of academics involved in educational research in Northern Ireland is small. However, it is a relatively vigorous community and a measure of the wide range of topics that they would wish to research was gained from a survey of the attendees at a research capacity building event in 2002. These topics are summarised in Table II.

\begin{tabular}{|c|c|c|c|c|c|}
\hline \multicolumn{6}{|c|}{ Research Needed in ... } \\
\hline $\begin{array}{l}\text { Young people } \\
\text { emerging into } \\
\text { adult life }\end{array}$ & $\begin{array}{l}\text { Alternative } \\
\text { education } \\
\text { provision }\end{array}$ & $\begin{array}{l}\text { Transition from } \\
\text { primary to } \\
\text { secondary }\end{array}$ & $\begin{array}{l}\text { Parental } \\
\text { engagement and } \\
\text { involvement }^{\star}\end{array}$ & $\begin{array}{l}\text { Conflict-related } \\
\text { impacts on } \\
\text { children }^{\star}\end{array}$ & $\begin{array}{l}\text { Learning in a } \\
\text { second } \\
\text { language }\end{array}$ \\
\hline $\begin{array}{l}\text { Reading } \\
\text { interventions }\end{array}$ & $\begin{array}{l}\text { Assessment and } \\
\text { attainment }\end{array}$ & $\begin{array}{l}\text { ICT in learning } \\
\text { and teaching }\end{array}$ & $\begin{array}{l}\text { Social inclusion } \\
\text { in schools }\end{array}$ & Policy evaluation & $\begin{array}{l}\text { Teaching } \\
\text { quality }\end{array}$ \\
\hline $\begin{array}{l}\text { Integrated } \\
\text { education }^{\star}\end{array}$ & Pupil voice ${ }^{\star}$ & $\begin{array}{l}\text { Literacy and } \\
\text { numeracy }^{\star}\end{array}$ & $\begin{array}{l}\text { Post-compulsory } \\
\text { education }\end{array}$ & $\begin{array}{l}\text { Enterprise } \\
\text { education }\end{array}$ & $\begin{array}{l}\text { Environmental } \\
\text { education }\end{array}$ \\
\hline $\begin{array}{l}\text { Values in } \\
\text { education }\end{array}$ & $\begin{array}{l}\text { School } \\
\text { improvement }\end{array}$ & $\begin{array}{l}\text { Post-11-plus } \\
\text { arrangements }\end{array}$ & $\begin{array}{l}\text { Teaching } \\
\text { strategies }\end{array}$ & $\begin{array}{l}\text { Multicultural } \\
\text { education }\end{array}$ & $\begin{array}{l}\text { Talking to } \\
\text { learn }\end{array}$ \\
\hline Early years ${ }^{\star}$ & Bullying ${ }^{\star}$ & Curriculum ${ }^{\star}$ & $\begin{array}{l}\text { Home-school } \\
\text { links }\end{array}$ & Small schools & Truancy \\
\hline
\end{tabular}

Table II. Wish list of research needs expressed by Northern Ireland academics in 2002.

The range of educational research topics that have been funded in recent years is quite wide. The topics marked with an asterisk in Table II are those that have been addressed by identifiable research projects, while beyond this list others include research in pupil suspension and exclusions, examining ways of alleviating the bureaucratic burden on schools, attitudes to education of the socially disadvantaged, research into personal and social education, statementing of pupils with special needs, interventions to tackle underachievement, careers education, the recruitment and retention of teachers and the education of children from the Irish Traveller community. By no means has all of this been carried out by higher education academics, nor has it been funded exclusively by the Department of Education. Apart from the charities and other agencies, the use of consultants, as mentioned above, absorbs considerable sums of research funding for a variety of activities. Analysis of the awards made by the Department of Education in the years 2002-05 illustrates this and is summarised in Table III.

\begin{tabular}{lrrrrrrrrr}
\hline & \multicolumn{1}{c}{2002} & $\%$ & \multicolumn{1}{c}{2003} & $\%$ & 2004 & $\%$ & 2005 & $\%$ & \multicolumn{1}{c}{ Totals } \\
\hline Consultancy & 21,500 & 20 & 96,057 & 27 & 87,595 & 50 & 430,280 & 63 & 635,432 \\
Academic & 85,596 & 80 & 255,116 & 73 & 87,914 & 50 & 254,176 & 37 & 682,802 \\
Totals & 107,096 & & 351,173 & & 175,509 & & 684,456 & & $1,318,234$ \\
\hline
\end{tabular}

Table III. Department of Education expenditure ( $($ ) on research and

evaluation through the academic and consultancy research sectors, 2002-05.

This analysis does not necessarily include research commissioned from either consultancy or university researchers by government-related agencies such as the Council for Curriculum, 
Examinations and Assessment or the ELBs. It also does not include relatively large sums of money invested in UK and international research programmes, many with British-based academic researchers. In recent years these have included the Effective Pre-School Provision in Northern Ireland project (EPPNI - funded to a total of $£ 647,132$ over several years), the PISA 2003 and 2006 studies and the ESRC Teaching and Learning Research Programme extensions in Northern Ireland.

Perhaps the most worrying aspect of this analysis from the university perspective, however, is the steady decline, from $80 \%$ in 2002 to $37 \%$ in 2005 , in the academic educational researchers' 'market share' of the research funds. Several explanations may be put forward for this situation. Perhaps the most likely of these relates to the nature of the research now being commissioned. A significant proportion of the awards to consultancies relates to work that perhaps is less academically attractive to educational researchers, for example, telephone or postal surveys in which the researchers simply prepare data for the commissioning body. Awards to PricewaterhouseCoopers during this period included work on a procurement strategy for the schools' estate $(£ 276,000)$, a nutritional standards pilot scheme in schools $(£ 45,000)$, an outline international strategic framework for the Department $(£ 11,000)$ and customer satisfaction surveys $(£ 33,000)$ in primary and secondary level schools relating to the major information technology developments carried out by $\mathrm{C} 2 \mathrm{~K}$ (http://www.c2kni.org.uk). Awards to other 'Consultancy Framework'-listed groups included $£ 40,000$ for a review of business education initiatives (Frontline) and $£ 13,000$ for a review of 'Children First', a childcare initiative (Capita). The largest award for a non-academic and non-'Consultancy Framework' group was to Pobal for a study of the special educational and health needs of bilingual (Irish-English) children from birth to 18 years of age.

While the academic dimensions may be a major factor in the decline of university educational researchers' market share, several other reasons may have some influence. First, there is the obvious research capacity problem borne out by the RAE submissions mentioned above; Northern Ireland recorded only 39 'active' educational researchers in the 2001 exercise. The availability of the relevant competence necessary to carry out the plethora of possible research studies is clearly constrained by such a small number. A second, more subtle influence of the RAE is the drive to apply for and win peer-reviewed research funds, a category of funding that is recognised as a crucial indicator when assessing a university's research quality. This imperative tends to subdue the pursuit of local funding initiatives when the key measure is research council or peer-reviewed charities' funding. A third factor may be the manner in which university academics bid for research, where the overhead costs are perhaps more explicit and cumbersome in calculation than the daily rate or block fee favoured by most consultancy organisations. It is not an uncommon experience to find a university bid losing to a lower consultancy bid because of the costing models. It is likely that in the short term at least, this situation will be exacerbated by the inception of the 'full economic costing (fEC)' model of research costing, which is now government-mandated for university research bidding.[3] This development makes research considerably more expensive for funding bodies as the government obliges them to pick up the infrastructural and indirect costs of carrying out research in universities.

Some of the potential consequences of the weak research capacity were revealed in the results of a series of interviews carried out by one of the present authors with key education stakeholders in 2002. The consensus that emerged was that educational research was ad hoc and fragmented, that no overall strategy could be discerned. In addition, much educational research was often perceived as being underfunded and poorly disseminated. Some academic research could also be simply marginal to the concerns of policy makers and practitioners. In response to this situation, local members of the Universities' Council for the Education of Teachers (UCET) and the British Educational Research Association (BERA) organised a conference in May 2002 to explore these issues further and, more particularly, to consider the potential priorities and beneficiaries of educational research. The dialogue between researchers and policy makers was further developed through a BERA colloquium in Edinburgh in November, 2002, in which an academic and a policy maker from each of the four regions of the UK made a presentation on a common research and policy theme (BERA, 2003). Further informal discussions in Northern Ireland eventually led to a roundtable discussion in January 2004, following which higher education researchers and representatives from the departments of Education, and Employment and Learning agreed on a number of developments. 
The higher education representatives recognised their responsibility to engage in capacitybuilding work, in particular through links with the Research Capacity Building Network of the Teaching and Learning Research Programme. In addition there was a commitment to strengthen collaborative links. The UNESCO Centre in the University of Ulster [4] represents a long-standing example of successful collaboration and Queen's has more recently established a formal partnership with the National Foundation for Educational Research (NFER) to establish a centre for educational research, known as NFER at Queens.[5] The centre aims to prioritise applied research and to capitalise on the synergy between local expertise in Queen's and the capacity provided by NFER. The Department of Education in turn agreed to address the need to reduce the ad hoc and fragmentary nature of much educational research activity in Northern Ireland by developing a more coherent strategy. To this end they introduced a set of five strategic themes for outline research funding proposals, which educational researchers were invited to address. One theme related primarily to the Department's own business (Organising for Success), while four were aimed directly at bringing direction and focus to the proposals being sent to the Department. These were:

- Valuing Education, including creating a desire for learning in young people;

- Fulfilling Potential, covering issues such as flexible learning opportunities, fostering personal development and providing skills for employment and lifelong learning for all young people;

- Promoting Equality and Inclusion, including the provision of equality of access, facilitation of parent choice and promoting respect for diversity, equality and human rights;

- Resourcing Education, including the procurement of sufficient funding for a quality education service, the efficient, effective and equitable use of resources, the provision of highly skilled and motivated teachers and high quality leadership and governance across the education sector.

These four themes later became the mainstays of the Department of Education's much broader Strategic Plan for Education: April 2006-March 2008 (DE, 2006a).

\section{The Political Economy of Educational Research}

Given the unusual history and structures of the education system in Northern Ireland, it is not surprising that these affected the nature and process of educational policy making and educational research. Of particular note has been the lack of accountability of the government system due to the long-term absence of locally elected politicians from the decision-making process, albeit with the brief hiatus between 2000 and 2002 when the Assembly was sitting. This has had at least three significant consequences for policy making and the educational research that might otherwise have informed it. First, there has been a perception among many in Northern Ireland that the Civil Service enjoys too much autonomy in the determination of policy. This is particularly felt to be the case in situations where a 'direct rule' minister either has little obvious interest in their Education brief on or is focused on other areas of their brief to the detriment of Education. Secondly, some major policy decisions resulting from developments in England are applied to Northern Ireland whether or not they are directly relevant to local concerns. Thirdly, and more subtly, local politicians have become accustomed to a situation where they have little direct influence on the levers of power or decision-making and, in this disempowered state, characteristically adopt relatively superficial populist positions on policy debates.

The significant expenditure on consultancy services as opposed to strategic research serves as an illustration of the first consequence. Government departments hire consultants to provide reports on specific issues, but despite the potentially large public sums involved few make it into the public domain. It is almost entirely a matter for the department concerned whether the reports are made public or are used internally to inform or perhaps even justify specific policy decisions. The absence of a locally functioning Assembly provides little or no prospect of the scrutiny of expenditure on consultants, as opposed to competitively tendered research. Furthermore, the lack of formal accountability procedures also means that that there is no external scrutiny of the reports themselves and no simple mechanism for ensuring they come into the public domain. There are some mechanisms for scrutiny through Westminster channels but these are limited. It was noticeable, in fact, that while the Assembly was operating during 2000-02 the volume of ministerial 
questions being dealt with by departments increased, and the existence of the formal Assembly Committees allowed for an alternative source of research and ideas on specific policy issues.

An example of the second consequence, where decisions applied to Northern Ireland have had their genesis in debates in England whether or not they were relevant to local concerns, is provided by the 1989 Education Order. This introduced a series of measures derived from the 1988 Education Act, including competition between schools, the introduction of school performance ('league') tables, increased parental choice, the introduction of a statutory curriculum and enhanced school inspection arrangements. These measures came from the Thatcher Government's strategy to weaken local authorities and apply market disciplines to education providers. The key lever for change was to be parental choice, with performance tables providing the data to inform choice; the statutory curriculum, assessment and inspections guaranteeing minimum standards of provision; and the devolution of administrative and financial responsibility to schools giving them the tools to improve their position within the educational market. These measures were designed for a comprehensive education system in England, but were applied largely unmodified to the selective system in Northern Ireland. In a system of academic selection, the notion of competition between grammar and secondary schools is somewhat nonsensical, given the de facto 'market advantage' of higher performance available to the selective grammar schools. The incongruity of the situation was heightened still further by the application of a statutory curriculum for all pupils up to age 16 years, whether in selective or non-selective schools. This situation has only recently changed with the passage of the Education (Northern Ireland) Order 2006 (DE, 2006b), which lays the basis for a more flexible curriculum and encourages collaboration among schools by requiring them to provide an 'entitlement curriculum' to all pupils aged 14-16 years.

Another aspect of the 2006 Order relates to the system of academic selection itself. The inglorious history of policy on this issue illustrates the power of external referents on local decision making. As noted above, the Advisory Council on Education recommended an end to academic selection in 1973. This recommendation was accepted by the then Labour Government under James Callaghan. Between 1976 and 1979 a series of changes were introduced into the selective arrangements as part of a transition to a non-selective system. These moves were fiercely opposed by the grammar schools but the key factor in changing the situation was the election of the first Thatcher government in 1979. One of the first acts of the new direct rule minister, with responsibility for Education, was to halt the transition to non-selective arrangements. Research carried out by the Northern Ireland Council for Educational Research in the 1980s (for example, Sutherland \& Gallagher, 1986; Teare \& Sutherland, 1988; Gallagher, 1988) was highly critical of aspects of the selective arrangements, but the government of the day was impervious to the evidence and unwilling to consider any proposals for change.

The situation shifted once more when the first Blair government was elected in 1997. Rather than simply change policy, a series of research studies were commissioned to provide evidence on the effects of the selective system and to inform public debate (see, for example, Alexander et al, 1998; Gallagher \& Smith, 2000). By this time the local Assembly was operating and a Sinn Fein Minister of Education was in office. He established the Post Primary Review Group to consider proposals for change and it duly reported in 2001 (Burns, 2001). There followed an extensive consultation on its recommendations and the results of the consultation were available in 2002. By this time the Assembly had gone into suspension, although not before the Minister for Education had announced the end of the use of 11-plus transfer tests (McGuinness, 2002).

The direct rule minister who took over the portfolio quickly ratified the decision to end the tests (Kennedy, 2002) and appointed a Post Primary Review Working Group with a remit to bring forward practical recommendations for change. Their report was made public in January 2004 (Costello, 2004) at which point the decision to abolish academic selection was confirmed. Since then there has been two years of intense political debate, culminating in the publication of the draft Education (Northern Ireland) Order in 2006 and its eventual passage through both houses of parliament. During this period the Government had been trying unsuccessfully to encourage the main political parties in Northern Ireland to agree arrangements for re-establishing the Assembly. It was therefore with a highly political sleight of hand that the direct-rule Secretary of State, Peter Hain, left an opening for pro-selective education politicians to reverse the abolition of selection. The 2006 Order abolishes selection with a clause prohibiting the use of academic criteria in the selection of pupils by post-primary schools. However, this clause, and only this clause, was left 
subject to a confirmatory vote of the Assembly, if it were to be re-established before the end of November 2006. If the politicians come together and restore the Assembly they will have the power to rescind the clause. Given the outcry of the unionist parties against the abolition of selection, and in particular the majority Democratic Unionist Party led by Ian Paisley, this is a powerful incentive to join in a power-sharing government with the nationalist parties. Despite all the research and consultation evidence, the selection debate has therefore become a political tool, designed to incentivise power-sharing.

Education policy is informed by many sources, and research evidence forms only one, albeit distinctive, source. At critical points in the debate over academic selection in Northern Ireland research evidence has played a role in reframing some of the assumptions involved in the discussion. Two examples illustrate this. First, in the debate in the 1970s the grammar school lobby was united in its opposition to change and included the Catholic bishops in Northern Ireland within its ranks. However, following the political agreement in 1998 the bishops established a working party to consider the contribution of Catholic education to the newly emerging opportunities provided by the peace process. Research evidence considered by the working party encouraged a focus on social justice issues, including a critique of the social inequities produced by the selective arrangements. When the more recent debate on selection re-emerged in the 2000s, the bishops were no longer staunch defenders of academic selection and made a formal commitment to the need for change.

The second example is more focused. The terms of reference for the Department of Education-funded research into the effects of the selective arrangements (Gallagher \& Smith, 2000) did not include provision for research on the technical merits or demerits of the 11-plus tests, but independent funding was secured to ensure this research was carried out. When this research was published it was damning in its criticism of the reliability and validity of the tests (full report: Gardner \& Cowan, 2000; see also Gardner \& Cowan, 2005). Thus, by the time the Post Primary Review Group completed its work in 2001, a significant amount of new research had entered the pubic domain. There were many years of fierce debate still to come but research had created an informed consensus: the 11-plus tests themselves were thoroughly discredited.

The two examples above show the way in which educational research may help to shape public discussion. However, the debate as a whole also shows the limitations of the research contribution: as we moved closer to a final decision on arrangements for post-primary education, the debate became increasingly focused on political considerations. Perhaps this is as it should be, but then the peculiar political arrangements of Northern Ireland play their role. As noted above, the third consequence of direct rule has been that the local political parties have not had access to the levers of power or decision making. This has also meant that they have not had to deal with the responsibilities of decision making and, more particularly, the experience of making choices between competing priorities. They have, in fact, been in a virtually permanent condition of opposition which permits them to oppose any unpopular decision promoted by the direct rule administration and argue in favour of 'additional resources' as a solution to every problem. Thus the debate on selection is argued by some to be a simple problem of allocating sufficient resources to create a process that validly and reliably differentiates between 11 year-olds on academic ability. Easily said but is it easily done? When you do not have to make the decision, much political capital can be made in ignoring the evidence and simply supporting the populist view. It almost goes without saying that in the brief period when local politicians were in control of decision making, few really difficult decisions were made, in education or in anything else.

\section{The Future for Educational Research}

\section{Research Capacity}

Taking stock of the situation, any objective observer is likely to identify several major challenges confronting educational research and the researchers themselves in Northern Ireland. Prime among these is the issue of research capacity. It is perhaps disappointing to many to see large sums of public money being diverted to private consultants, for work that could be carried out by academic educational researchers. The bonus with the latter would be the greater prospect of more of this work reaching the public domain, and to increase the collective knowledge and 
understanding of the complexities faced. In reality, though, there may not be sufficient academic researchers to carry out the work and if anything the numbers may be decreasing as a result of the advanced age profile across the educational research sector as a whole (for example, more than $52 \%$ are over 50 years of age and only $8 \%$ are under 34 years of age; see Mills et al, 2006, p. 44). Furthermore, with such small numbers of academic researchers in Northern Ireland, the likelihood that the appropriate competence exists for any particular type or topic of research may also be low. A system awash with educational researchers is not a complication that is likely to arise but concerted efforts are clearly needed to create a sustainable 'community of practice' that will increase the numbers of competent educational researchers available in the future and will also promote the inter-institutional collaboration that will provide a more solid research base.

\section{Strategic Direction}

A second challenge relates to the need for a strategic direction and structure. Earlier it was suggested that the more instrumental survey-type work, currently directed more towards commercial consultants through a select tendering process, may not be attractive to academic researchers who are continually being pressed by their institutions to seek peer-reviewed funds. If educational researchers continue to resist or withdraw from such work the $80 \%$ market share of the Department of Education funds for 2005 won by private consultants is likely to be consolidated and perhaps increased. Government departments tend to want research findings 'yesterday' for decisions to be made 'today' while much of the peer-reviewed research, to which academic researchers are drawn, requires more sophisticated attention and therefore more time than perhaps some decision contexts can accommodate. Given that the Government and its agencies will always need 'quick and dirty' research, the challenge for educational researchers is to engage with government departments in developing a projective research strategy. Such a strategy would aim to identify what research is needed before it develops the 'yesterday' urgency that can reduce research to 'quick and dirty' exigencies. It would also aim to plan for the type of research and competence needed to address the identified needs.

\section{Innovation}

A third challenge derives from the perspective that research can develop new knowledge, explore new practices and create new understandings. The pace and pressure that characterises educational contexts today leaves little opportunity for genuine innovation but now and again 'experimental' work (in the innovative rather than methodological sense) attracts funds and pushes out the boundaries. One recent example of this in Northern Ireland has been the tripartite collaboration (Queen's researchers with experts from the Council for Curriculum, Examinations and Assessment and the Belfast Education and Library Board) that has trialled an 'enriched curriculum' specifically for early years children from severely disadvantaged areas of Belfast.[6] However, there is insufficient opportunity for innovative work, especially when the main role for research seems so resolutely instrumental. Yet a vigorous research community thrives on the innovation of new ideas, new methods and new insights. The dual challenge for academic researchers, then, is to come up with the ideas and to persuade funding bodies that there is merit in supporting such innovative research.

\section{Accommodating the Instrumental}

It can be argued reasonably successfully that educational research in the highly politicised and divided society that is Northern Ireland is primarily instrumental. Yet it may be no less important for that and educational researchers must accept the challenge of accommodating it. Instrumental research in Northern Ireland is important in the same way as anywhere else in the world, because despite the trappings of utility, the researchers can continue to aim to develop new knowledge and to offer new insights into the complex social phenomena that make up a national educational system. These insights and new knowledge can combine to assist in improving the education of all learners through promoting better policy making and better practice. Such outcomes are capable of 
being realised so long as researchers offer high-quality work by, for example, addressing the mantra of good practice: good planning and design, appropriate methods and making the findings accessible to the policy maker and practitioner audiences.

That much of the research undertaken in Northern Ireland may be primarily instrumental is not unreasonable per se, but the example of selective education research above suggests that research can just as easily lose its utility or have its utility rejected, depending on whether it is acceptable to a particular political position or makes policy implementation problematic. Vestergaard (2004) has argued that research, 'Formerly an intellectually autonomous phenomenon within society ... is rapidly developing as an official entity like other state entities and thus losing its particularity. ... it is not appropriate to have the results or focus of research determined solely by official needs and imperatives. Critically, the essence of research is in and of itself (p. 85). Such notions may be wishful thinking, to be banished relatively quickly by the political influences and practical requirements to be found in most educational research contexts. In Northern Ireland the story of the research-informed selection debate illustrates that even when research helps to 'gauge the deliverable', political expedient may ultimately mean that significant educational decisions turn less on painstaking research evidence and more on political guile.

\section{Notes}

[1] http://news.bbc.co.uk/1/hi/events/northern_ireland/history/68824.stm)

[2] http://www2.deni.gov.uk/inspection_services

[3] Details of the fEC are available from: http://www.pparc.ac.uk/jes/DualSupport.asp

[4] http:/ / www.ulster.ac.uk/faculty/shse/unesco

[5] http:/ /www.qub.ac.uk/nfer

[6] http:/ / www.psych.qub.ac.uk/research/projects/ey/index.aspx

\section{References}

Alexander, J., Daly, P., Gallagher, A.M., Gray, C. \& Sutherland, A. (1998) An Evaluation of the Craigavon TwoTier System. Research Report No. 12. Bangor: Department of Education.

Brady, L. (2006) Key Education Statistics: Northern Ireland in context, in C. Donnelly, P. McKeown $\&$ B. Osborne (Eds) Devolution and Pluralism in Education in Northern Ireland, pp. 188-201. Manchester: Manchester University Press.

British Educational Research Association (2003) Educational Policy and Research across the UK. Report of a BERA Colloquium held at the University of Edinburgh, November 2002.

Burges Report (1973) Reorganization of Secondary Education in Northern Ireland. Report of the Advisory Council for Education. Cmd. 574. Belfast: HMSO.

Burns, G. (2001) Education for the 21st Century. Report of the Review Body on Post-Primary Education (Burns Report). http: / /www.deni.gov.uk/22-ppa_burnsreport_summary.pdf

Costello, S. (2004) Future Post-Primary Arrangements in Northern Ireland (Costello Report). http:/ / www.deni.gov.uk/index/22-postprimaryarrangements-new-arrangements_pg.htm (accessed 31 July 2006).

Department of Education (2006a) Strategic Plan for Education: April 2006-March 2007. Bangor: Department of Education. http://www.deni.gov.uk/strategic_plan_for_education_2006-08_pdf_-_161_kb-2.pdf, (accessed 31 July 2006).

Department of Education (2006b) The Education (Northern Ireland) Order 2006. Bangor: Department of Education. http://www.deni.gov.uk/22-ppa-education_bill_9_june_2006_final.pdf (accessed 31 July 2006).

Elliot, S. (2006) What is the d'Hondt System? http: / www.nilga.org/con_faq.php (accessed 31 July 2006).

Gallagher, A.M. (1988) Transfer Pupils at 16. Belfast: Northern Ireland Council for Educational Research.

Gallagher, T. \& Smith, A. (2000) The Effects of the Selective System of Secondary Education in Northern Ireland: Main Report. Bangor: Department of Education. 
Gardner, J. \& Cowan, P. (2000) Testing the Test: a study of the reliability and validity of the Northern Ireland Transfer Procedure Test in enabling the selection of pupils for grammar school places. Full Report. Belfast: Queen's University Graduate School of Education.

Gardner, J. \& Cowan, P. (2005) The Fallibility of High Stakes '11-plus' Testing in Northern Ireland, Assessment in Education, 12(2), pp. 145-165. http:/ / dx.doi.org/10.1080/09695940500143837

Gray, C. \& Gardner, J. (1999) The Impact of School Inspections, Oxford Review of Education, 25(4), pp. 455-468. http: / / dx.doi.org/10.1080/030549899103928

Hamilton, N. (2003) Foreword, in Economic Policy Unit A Practical Guide to Policy Making in Northern Ireland. Belfast: Office of the First Minister and Deputy First Minister.

Harland, J., Moor, H., Lord, P., Kinder, K., Kaur, S., Johnson, F. \& Dingle, R. (2003) Talking 4: the pupil voice on the Key Stage 4 curriculum. Belfast: Council for the Curriculum, Examinations and Assessment.

Kennedy, J. (2002) Kennedy Confirms the Tests Will Go. Press release, 31 October 2002. Bangor: Department of Education. http:/ / www.nics.gov.uk/press/edu/021031e-edu.htm (accessed 31 July 2006).

McGuinness, M. (2002) McGuinness Announces Transfers Tests Are to Go, Press release, 8 October 2002. Bangor: Department of Education.

Mills, D., Jepson, A., Coxon, T., Easterby-Smith, M., Hawkins, P. \& Spencer, J. (2006) Demographic Review of the Social Sciences: final report. Commissioned by the Economic and Social Research Council. Swindon: ESRC. http:/ / www.esrc.ac.uk/ESRCInfoCentre/Images/Demographic_Review_tcm6-13872.pdf (accessed 31 July 2006).

Moor, H., Bedford, N., Johnson, A., Hall, M. \& Harland, J. (2004) Moving Forward; thinking back: young people's post-16 paths and perspectives on education, training and employment. Belfast: Council for the Curriculum, Examinations and Assessment.

Organisation for Economic Cooperation and Development (2003) Programme for International Student Assessment, PISA. http://www.oecd.org/pages/0,2966,en_32252351_32235731_1_1_1_1_1,00.html (accessed 31 July 2006).

Official Journal of the European Union (OJEU) (2005) Invitation to Tender No. 233190-2005, UK-Belfast: General Management Consultancy Services. Central Procurement Directorate for Northern Ireland, Official Journal of the European Union, 8 December 2005.

Public Accounts Committee of the Northern Ireland Assembly (PAC) (2002) 10th Report Minutes of Evidence, paras 99-105. http:/ / www.niassembly.gov.uk/public/reports/report10-01r.htm (accessed 31 July 2006).

Research Assessment Exercise (RAE) (2001) Unit of Assessment 68: Education. http:/ / www.hero.ac.uk/rae/rae_dynamic.cfm?myURL=http:/ 195.194.167.103/Results/byuoa/uoa68. htm (accessed 31 July 2006).

Sutherland, A.E. \& Gallagher, A.M. (1986) Transfer and the Upper Primary School. Belfast: Northern Ireland Council for Educational Research.

Teare, S. \& Sutherland, A.E. (1988) At Sixes and Sevens. Belfast: Northern Ireland Council for Educational Research.

Vestergaard, E. (2004) Aspects of European Research Policy Experience Relevant to the Humanities and Social Sciences, in M. MacLachlan \& M. Caball Social Science in the Knowledge Society: research policy in Ireland, pp. 81-90. Dublin: Liffey Press.

JOHN GARDNER is Professor of Education in the School of Education at Queen's University, Belfast. His main research areas include policy and practice in education, particularly in assessment and information technology in education. Since 1990, he has been principal investigator in over twenty large- and small-scale projects including research on, for example, the reliability and validity of the 11-plus tests in Northern Ireland, consumer education needs, Reading Recovery and virtual learning environments. He has published over 100 scholarly publications and five books. He is a fellow of the British Computer Society, a member of Council for the British Educational Research Association, a member of the Steering Committee of the Economic and Social Research Council Teaching and Learning Research Programme and a vice-chair of the Academy of Learned Societies in the Social Sciences. Correspondence: Professor John Gardner, School of Education, Queen's University, Belfast BT7 1HL, United Kingdom (j.gardner@qub.ac.uk). 
John Gardner \& Tony Gallagher

TONY GALLAGHER is a Professor at Queen's University, Belfast and head of the School of Education. His most recent book is Education in Divided Societies (Palgrave Macmillan, 2004), and he is editor of Education, Citizenship and Social Justice (Sage). Correspondence: Professor Tony Gallagher, School of Education, Queen's University, Belfast BT7 1HL, United Kingdom (am.gallagher@qub.ac.uk). 